\title{
Don Delillo's White Noise: \\ A Place- Based Ecological Study
}

\author{
Manal Anwar Beizak* \\ maf01@fayoum.edu.eg
}

\begin{abstract}
The concept of place has become a basic concern in almost all works that handle an ecological issue. The purpose of this paper is to examine Don Delillo's White Noise from a place-based perspective. The study is a critical analysis of the major places of the novel. It proves that in this post- modern society the stereotypes of home as a safe, comfortable place and the supermarket as a place for purchasing some daily needs are converted. The novel depicts the family of Jack Gladney, a college professor, who live in a modern town, Blacksmith. However, a great part of the novel traces an accident of a train loaded with tanks of a poisonous gas causing a black poisonous cloud. This dangerous cloud sharply affects the behavior of people so that they become obsessed with the fear of death. Among the major places chosen for study are: the house, the state of being placeless, the camp, the school, the insane asylum, the place of medical examination, a hotel room, and the supermarket.
\end{abstract}

Key Words: eco-criticism, eco-justice, ecocide, sense of place, White Noise, Don Delillo.

*English Dept., Faculty of Arts, Fayoum University. 
The increasing interest in ecological studies and eco-critical literature throughout the last decade of the twentieth century highlights place as a central element of critical concern in almost all literary works. Noticeably, most of the ecological issues as climate change, pollution, toxic waste, global warming, and place attachment, are relevant to a sense of place. The purpose of this paper is to examine Don DeLillo's White Noise from a placebased perspective. As place has become one of the most critical concerns of the ecological studies, the study aims at analyzing the major places of the novel from a critical view. It is a comprehensive critical analysis of the element of place. However, as a focal eco-critical concern, place is not only connected with open spaces of nature but it is also interrelated with all local places in modern societies.

White Noise is a post- modern novel that portrays a modern society with its technologies, commercials, consuming capitalism, mass media, and polluted environment. The study examines the various types of place in the novel and proves that in post-modern societies most of the common stereotypes of place are no longer found. The stereotypes of home as a safe, comfortable place and the supermarket as a place just for purchasing our daily needs are converted. Furthermore, the study expounds that the great changes of usual functions of places and of the environment in 
general are due to the maltreatment and the selfish exploitation of human beings to their environment.

Kibler et al. notice that the term 'sense of place' was first introduced in 1977 by Tuan as "the meaning an individual or group ascribes to a geographical location" (Kibler et al. 2). Moreover, Kibler argues that expounding sense of place from a social science point of view, reveals its interest in "three related characteristics: a physical location, activities in that location, and meanings and attachments connected to human experiences and psychological connections to the physical location" ( 2). Similarly, Quinn et al. indicate that studying the sense of place concentrates on "measuring the strength of attachment to a place" (3). In the meantime they explain that place attachment reflects "the strength of feeling for a place" and "the symbolic significance of a place to a person" (3). Thus, each place has its own meaning and value for the person.

Likewise, Derek Gladwin believes that the concept of place "remains a fundamental principle of eco-criticism because of its application in both literary and ecological theories" (1). This is due to the fact that the writers of such works examine how people differently react with the other creatures and the nonhuman objects around them. Place also reflects the cultural and social surroundings of people. Moreover, place is a strong indicator of people's values and ethics. The nature of a place does not only 
specify certain types of work but it also imposes certain set of ethics and codes of behavior. Gladwin notices that Jeff Malpas, one of the philosophers of place studies, considers place as the "key term for interdisciplinary research in the arts, humanities and social science in the twenty- first century" (5). However, it is not easy to define the concept of place as it includes a lot of interpretations. It has geographical, social, philosophical, and emotional meanings.

For eco-critics whose main concern is human-nature relationship, place is of focal importance. It is more than the local environment of people. They think of place as a "living physical location, geographical and biological, as well as subjective human experience"(Ball 238). Place for them is not only the setting or the local environment in which some events take place, but it is the location of people's different human experiences. Ball affirms Evernden's opinion that "place-as- environment and place- assubjective experience are equally interrelated, inseparable, and interdependent as are organisms and environments themselves" (Ball 237). This clarifies that every individual thinks of his place as the setting that is connected to his achievements, memories, success and failure. It is related to his entire life and it is the role of literature then to explore and examine these relationships. This is why every literature has distinctive characteristics according to 
the places it depicts particularly when authors depend on place as a main theme or a literary technique.

In his book The Role of Place in Literature (1984), Leonard Lutwack argues that literature "always reflects ambivalent attitudes toward earth and its constituent places" (11). In literary works, it is noted that the bond between individuals and places is not limited to the mere mutual interaction, but that it is the places which play a dominant role in forming the personalities of these individuals. Moreover, Lutwack differentiates between 'setting' and 'place' explaining that 'setting' describes the scene or the place of action in both novels and plays but it is only "an important category of place in literature" (28). This is due to the fact that setting is not sufficient to describe "the use of places unrelated to action, such as metaphors or evocations of places in the speeches or consciousness of characters" (28). Thus, setting is "a concentrated and persisting occurrence of place in literature, whereas place imagery and place allusions are ubiquitous and fleeting, though they may have a powerful cumulative effect"(28). Therefore, place is more complicated and more comprehensive than setting. At the same vein, Kincheloe and Pinar consider place as "the life-force of fiction, ..., the playing field on which drama evolves" so that the reader easily "decodes the subtle imprint of place on both the unfolding of theme and the development of character"(Introduction, 4). 
Place is not only connected with human experiences but it also affects the personal values of people. Eric Ball argues that "since places are frames of social relations, they become imbued with the values of these relations and therefore help to create the relational values that make up the self"(241). Even people's different values are derived from the place in which they live. This confirms what Masterson et al. call "place identity" which they identify as "those dimensions of the self that define the individual's personal identity in relation to the physical environment" (3). This shows how various place elements have a role in the self- formation. This applies to the opinion of Kincheloe and Pinar that the "sense of place sharpens our understanding of the individual and the psychic and social forces that direct him or her" (Introduction, 4).

Handling the importance of place, Marla Morris expounds that the ecojustice scholars David Gruenewald and Gregory Smith argue that "critical issues of race, gender and other aspects of culture can become abstractions unless these issues are grounded in concrete experience, experience that always takes place somewhere" (145). This is because eco-justice is related to the institutional, social and cultural conduct of a country according to its social structure. It also shows how wealthy people can resort to their money to overcome environmental disasters. By money they can purchase healthy and clean places to live in. It is only 
the poor who have to endure the ecological catastrophes because they have no alternatives. Thus, eco-justice exposes the unjust discrimination suffered by the poor in all impoverished areas of the world. Likewise, Kortetmaki believes that it is the job of ecojustice to handle the "impediments of justice that are rooted in the societal structures and social and cultural practices" (107). Therefore, it is logical to examine such issues in a specific place to be fairly evaluated. Similarly, environmental education begins to focus more on the place on which we live. This is confirmed by Michiel Van Eijck who thinks that environmental education "has recently moved towards more place-based approaches"(Morris 146).

Glen A. Love notices that scholars from various disciplines "affirm human connections to place as profoundly important and interesting" so that the result of their studies is "a virtual new science of place which cries out for attention from literary scholars" (579). In addition, Love confirms that Joseph Meeker's book The Comedy of Survival: Studies in Literary Ecology (1974) calls for examining how literature affects both "the human behavior and the natural environment" so as to explore "what insight it offers into human relationships with other species and with the world around us" (Love 564). Therefore, many works of art can be examined with an ecological awareness in order to 
analyze the interrelationships between human individuals and non-human elements.

Don Delillo's 1985 National Book Award winner, White Noise, can be examined from a place-based point of view. Such examination reveals how the places are portrayed in post- modern standards so as to affirm the interrelationships between the characters and the places in which they live. The novel depicts the family of Jack Gladney, a college professor, who live in a neat, modern town, Blacksmith. However, a great part of the novel tackles an accident of a train loaded with tanks of a poisonous gas causing a black poisonous cloud. Known as The Airborne Toxic Event, this poisonous cloud sharply affects the behavior of people and makes them obsessed with the fear of death. Among the major places chosen for study are: the house, the state of being placeless, the camp, the school, the insane asylum, the place of medical examination, a hotel room, and the supermarket.

Houses in White Noise have specific characteristics and constitutions. The house is supposed to be the individual's private shelter which cut him from the outside world. It should be the place of comfort and safety that is supervised mainly by the mother and the moral and financial support of the father or both parents. However, houses in White Noise are far from this concept. Murray, the friend of the hero of the novel, lives in a 
rooming house where he feels "totally captivated and intrigued"(10). This reveals that it is a suffocating and psychologically uncomfortable place. Moreover, it is a "gorgeous old crumbling" house which is near the insane asylum. It seems that its location reflects the insanity and unhappiness of the modern world. Furthermore, all the inhabitants of the rooms are mysterious, isolated, inactive, rootless or shameful. Some of them are "A woman who harbors a terrible secret. A man with a haunted look". Others are "A man with no past. A woman with a past"(10). Murray talks about them in a detached, remote way. Murray concludes that the place of his residence is "the place of unhappy lives"(10). It is a place where there is no intimacy, friendship, confidence, respect or any human relationships among its tenants. It is like a microcosm of the modern societies in general.

Likewise, Jack Gladney's house is another example of modern homes. Jack lives in Blacksmith, a quiet town, with his wife, Babette, and four of their children from earlier marriages. Throughout the novel, various half siblings and ex-spouses drift in and out of the family's house. Here, there is a clear example of a disintegrated family where children live with their half parents. Moreover, their house is at the end of a quiet street in "what was once a wooded area with deep ravines"(4). So there is an eradication of some elements of nature to be replaced by different 
buildings and blocks of cement. This also reveals a materialistic, pragmatic way of life that does not care about vegetation or the beauty of nature.

At Jack's house there is a Friday night ritual in which the whole family gathers to watch television. Babette believes that turning television into a wholesome domestic activity will deglamorize it in the children's eyes and reduce its negative effects. She thinks that watching television one night a week with parents or stepparents is enough to limit its effect. However, Jack, who is also the narrator of the novel, considers Friday night "a subtle form of punishment for us all" (16). Jack and his son, Heinrich, get bored while Steffie becomes upset if anything shameful happens to someone on the screen. The time of the whole family together in front of the television is not amusing or enjoyable at all. It is a boring routine so that it is considered a kind of punishment.

During another Friday night, the family gathered in front of the television set. This time there were a lot of natural catastrophes such as floods, volcanoes and earthquakes on the screen. Strangely enough, they were so attentive that they were "totally absorbed in those documentary clips of calamity and death"(64). They not only enjoyed watching houses slide into the ocean and whole villages crackle in a mass of lava, but they also wished for bigger and grander disasters. Later on, Jack asks his colleague, 
Alfonse, why people are not annoyed by catastrophes when they watch them on television. He felt it strange to rejoice watching lava, mud slides, raging water, coastal erosion and mass killing. Alfonse's interpretation is that the human mind gets bored of graphics, numbers, facts and statistics so that only a catastrophe gets its attention. People enjoy disasters "as long as they happen somewhere else"(66). Again the indifference and selfishness of the modern man appears very flagrantly. Sheltered people do not think of the sufferings and predicaments of the placeless victims of natural disasters. They are protected by their own places which shield them from any fatal catastrophe. Watching television makes people feel that they are far away from these dangerous places and horrible events.

A similar impression appears during the beginning of the airborne toxic event when a tank car derailed causing a black billowing cloud of a poisonous gas, Nyodene D. Again, Jack thinks that he is a college professor living in a neat and pleasant town so he cannot be harmed. The idea of place as a shelter is dominant here as Jack believes that "these things don't happen in places like Blacksmith"(114). For him, Blacksmith is a civilized town with advanced, modern standards. It is "a town of dry cleaning and opticians"(59). Thinking of his town and his house as a place of great shelter, Jack tries to assure his wife that nothing harmful would happen to them. He believes that harmful 
things "happen to poor people who live in exposed areas"(114). Here, the concept of place as a source of personal shelter, protection and confidence, is prominent. According to Jack, it is the idea of being placeless that should annoy a person. Moreover, he is aware of the lack of ecojustice believing that "it's the poor and the uneducated who suffer the main impact of natural and man-made disasters"(114). Floods attack those who live in "lowlying areas" whereas "hurricanes and tornadoes" destroy people who live in "shanties"(114). It seems as if each caste of the poor has the natural catastrophe that suits it. This is because they live in fragile, badly-equipped places.

In contrast, Jack thinks of himself and his family as protected people far away from this mist of smoke. He argues with his son, Heinrich, saying "the important thing is location. It's there, we are here"(117). In addition, Jack cannot imagine leaving his house as a precaution to avoid the approaching dangerous cloud. He protested against this idea saying "I don't see myself fleeing an air borne toxic event. That's for poor people who live in mobile homes out in the scrubby parts of the county, where the fish hatcheries are"(117). Till this moment Jack thinks proudly of his house as a sufficient fortification that can face any outer danger or any kind of natural disaster. He thinks arrogantly hinting that ecological justice is something denied to the poor. It is a kind of institutional, social and cultural injustice. Fledman argues that 
environmental justice draws attention to "the uneven distribution of environmental benefits and harms" and that it handles "factors such as gender, age, class, and citizenship status" (introduction, 205).

However, returning home after a nine days evacuation with Jack's obsession with the fear of death, the house loses its safety and comfort. He discovers that his wife, Babette, has secretly been taking an advanced kind of psycho-pharmaceutical drug labeled Dylar in an attempt to alleviate her own fear of death. Moreover, she admits to having had an affair with the Dylar project manager in exchange for the pills. This is a great shock to Jack who highly appreciates Babette's honesty and sincerity in contrast with his previous secretive and closed off wives. The dual confession of Babette about her infidelity and her use of Dylar shake their healthy, loving relationship. It makes their house a place full of anxiety, intrigue and fear. Ambiguity and lack of confidence are established between the couple. Her infidelity infuriates his wounded dignity and his jealousy as a husband. It also leads to his obsession with the idea of revenge to destroy the project manager. Thus Jack's house is no longer a protective, comfortable place.

Besides the horrible behavior of his wife, Jack's house is represented, like all modern houses, as a dangerous place full of fatal radiation. Jack's son, Heinrich warns him that the most 
dangerous thing lies in "the things right around you in your own house that'll get you sooner or later. It's the electrical and magnetic fields"(175). He ascribes the increase of suicide rate to living near high voltage power lines. Wires and utility poles make those people sad and depressed. He even accuses radio and television of causing dangerous health troubles as nerve disorders, violent behavior in the home and also deformed babies. Here, DeLillo highlights the danger of extravagant dependence on technology in everyday life to the extent of being fatal to the human health. As all modern houses teem with electrical equipment, they are no longer safe places. Heinrich's warnings focus on the havoc caused by increased shortsighted technological practices.

During the evacuation that takes place at the time of the airborne toxic event, a technician checks Jack for signs of Nyodene D., which he may have been exposed to while pumping gas in a filling station. The man tells Jack that there are traces of Nyodene in his body which will live for thirty years. Jack contemplates how death adopts to the technological advances and how he has now the seeds of death planted inside him. Here jack's vague fear of death becomes confirmed. He now sees himself as a man destined to die and this knowledge affects his thoughts and action greatly. His search for comfort seems 
desperate and infantile. The airborne toxic event has become the modern shape of death.

After returning home from another visit to the doctor, Jack starts to throw things away. He moves through the house, throwing away all kinds of clutter. He throws old furniture, picture frames, TV trays, manuscripts of articles and a lot of other things. It seems that Jack's faith in these things as a means to protect him from death is beginning to disintegrate. He may think there will not be enough time to need such things in the future. Neither the house nor his other possessions can stop death from attacking him. He considers these things "an overburdening weight, a connection, a mortality"(262). In an hour he gets everything down to the sidewalk. He enjoys the act of throwing in itself so that he does not want "help, or company, or human understanding"(262). After getting the stuff out of the house, he sits "on the front steps alone, waiting for a sense of ease and peace to settle the air around [him]"(262). Jack resorts to an open place, the street, searching for rest and comfort in the open air. Now the house loses its role as a place of shelter and becomes a suffocating place filled with unnecessary things.

In contrast to the house as an example of an inner, private place, there is the case of being homeless. The most salient incident in which we witness the characters of White Noise placeless takes place during the airborne toxic event. At that 
urgent time the officials order people to evacuate. Accompanied by sirens, a voice screams out "Evacuate all places of residence. Cloud of deadly chemicals, cloud of deadly chemicals"(119). In twenty minutes jack's family is in the car directed by the voice on the radio to head for the Boy Scout Camp. The distance from the house to the camp reveals a horrible time of placeless, lost people. The conduct of people at these terrifying moments reflects how homeless people live in a horrible plight.

During their journey to the camp, Jack's family joined the crowded traffic flow. An amplified voice above them called "Abandon all domiciles, Now, now. Toxic event, chemical cloud" (120). All people were in panic and as they were homeless, all their reactions were exposed to the public. Some people were on foot carrying suitcases, boxes and blankets. Others carried their pets or children. Other people wear blankets. There were people on bicycles and others with supermarket carts. The scene described here reveals the pandemonium of mass evacuations and the fear of death by which all people are obsessed. People became "a parade of fools, open not only to the effects of chemical fallout but the scornful judgment of other people"(121). Being homeless deprives normal people of any kind of shelter, privacy or secrecy. Marla Morris thinks that "to be displaced causes emotional and intellectual estrangement"(153). All people are perplexed and no one knows 
what to do. Added to this, is their horrible fear of the black cloud, the airborne toxic event, which has become "like some death ship in a Norse legend"(127). The mythological reference here is to convey a kind of epic panic and great predicament. As the black cloud was "packed with chlorides, benzines, phenols, hydrocarbons, or whatever the precise toxic content", it represents "death made into the laboratory, defined and measurable -" (127). This is a salient example of ecocide where the environment is deliberately damaged by the human conduct. In contrast with natural disasters such as tornadoes or floods, the toxic cloud is a man-made disaster. People suffer the consequences of destroying the environment by becoming homeless. They are placeless, pursued by death and no one can help the other or even himself. Leonard Lutwack argues that the "sense of place inherited from Renaissance exploration and romantic identification has yielded in the twentieth century to a sense of place- loss and a sense of placelessness" ( 11).

Even the camp consisted of seven or eight buildings so there was no room for all people. Therefore, some families were forced to sleep in their cars. At the camp, people stayed in large barracks supervised by the Red Cross. Though they were offered food, coffee and portable heaters, the place was still crowded and quite cold. However, the existence of "other stranded souls" that include infants, old and infirm people, gave them "a selfless bent" 
that functions as "a common identity"(129). Being homeless, people begin to reduce their aspirations of a comfortable life. They start to think of those who suffer more than them. Their circumstances are similar to those of helpless refugees. This confirms that it is the individual's house which provides him with safety, confidence and pride. Contemplating their hard conditions, Jack thought of themselves as "forced out of [their] homes, sent streaming into the bitter night, pursued by a toxic cloud, crammed together in makeshift quarters, ambiguously death-sentenced"(146). Most of their horrible conditions are due to being homeless. They are roaming at cold night with the crowd to escape the death that pursue them instead of staying protected and warm indoors. Thus, being homeless deprived them of both physical and psychological comfort.

During the last days at the camp appears the image of place as a prison for dangerous people. At that time people are quarantined at the camp. One of the residents of the camp becomes so furious that he explodes saying "We are like lepers in medieval times. They won't let us out of here. They leave food at the foot of the stairs and tiptoe away to safety" (162). There is here the image of a terrifying place, full of sickness and danger. It is unsafe for the people who are outside it. Moreover, the people inside this place feel imprisoned and dehumanized by the others 
who offer them food in an insulting way. The camp is treated as if it were a place infested with sickness and death.

The other place in White Noise that is once depicted as a place of contamination and sickness is the school of Jack's kids. Even before the dangerous airborne toxic event, the grade school was evacuated. The kids experienced horrible symptoms as they tasted metal in their mouths and they had headache and eye irritation. Furthermore, a teacher rolled on the floor hallucinating. However, the causes of these horrible symptoms were not discovered. The investigators said that it could be the ventilating system, the paint, the electrical insulation, the rays of the microcomputers, the cafeteria food or anything used by the kids of the school. Here, the school is not depicted as the place of education and knowledge but as a polluted, contaminated place. The troubles that took place at the school are due to the excessive use of technology and modern inventions in the modern societies. The suspected things that caused these terrifying symptoms are either made from synthesized material, or they release electromagnetic rays. This corresponds with Murray's view that "[e]very advance in technology and technique is matched by a new kind of death"(150). Thus, the school has become a dangerous place that should be evacuated and checked in order to save the lives of the kids and teachers. 
However, the unusual place that is repeatedly mentioned in White Noise is the insane asylum. It seems that DeLillo believes in the necessity of the existence of such a place in the modern world so that he frequently refers to it from the very beginning of the novel. He mentions it in chapter 1 while he is setting the scene of the novel. Again, when jack goes to visit his fellow, Murray, he sees the insane asylum. It is near Murray's place of residence. Murray tells Jack that he does not hear neither beatings nor shrieks coming from the place. Ironically, this reflects that the noise of the sane world is more than the clamor of the insane people. Moreover, he admires its attracting structure, high steep roof and its tall chimneys. However, he does not think of it as a psychiatric facility. It seems that the outer shape of the building does not reflect the factual functions of it. Its striking shape does not indicate the abnormal deeds of the insane people.

Later on, the building of the insane asylum burns down at night. It is suspected that the flames are due to faulty electrical wiring. The flames roar through the building burning part of the roof and a tall chimney. Jack and his son watch firemen arriving to save the place. They save a white-haired mad woman from fire when she walks across the lawn. This incident depicts the place of the insane asylum as unsafe place and its residents become placeless in an instant. Its striking structure and prominent shape cannot protect it from flames. When firemen manage to 
extinguish the fire, odor of smoke and a bitter stink filled the air. It reminds people of death especially burning as a kind of "synthetic" death (240). Jack begins to think of the homeless and the mad as victims of this horrible incident. DeLillo repeatedly mentions the insane asylum to remind his readers of those helpless people who are not aware of their suffering. He also affirms that the existence of such a place is something factual in the modern world.

Another important place in the novel is the place in which Jack takes his medical examination. Its name is extraordinary as it is called Autumn Harvest Farms. The place is a pale building, one story, with bright lighting. Jack astonishingly thinks of the strange name of the place. It does not indicate that it is for examining or treating human beings at all. He thinks that a place with such a name might discover dangerous diseases. This name is very harsh and implies a kind of dehumanization to its visitors. Human beings who enter this place are coldly examined by advanced instruments and modern equipment as if they were nothing more than some samples, figures and ratios. N. H. Reeve and Richard Kerridge believe that in that world man's "physical being is viewed quite impersonally, as a system of chemicals whose inconveniences can be controlled or replaced by different chemicals" (314). 
In Autumn Harvest Farms they took Jack's samples away and he had to respond to questions on the screen of a computer. The place is unfriendly, ambiguous and emotionless. Jack walked through "narrow corridors", entered "room after room" and small "cubicles", "mazelike halls", and he stood in "a room the size of a closet" (276). In these places he was treated mechanically and he was seriously checked. However, in that place there were no human relationships as "[n]o one said hello" and his fellow patients were "faceless"(276). Every part of Jack's body was examined to know everything about it. The person at this place is the sum of figures and the results of samples. People at the Autumn Harvest Farms go from room to room and from a technician to another "like wandering souls"(276). There is no individuality or personal names as it is a place of scientific examinations and precise results only.

Searching for the Dylar project manager who seduced Babette in exchange for the pills, Jack decides to go to his place of residence. He knows that the man, Mink, lives in a hotel room in an unnoticed building so as to interview volunteers in the deepest secrecy. It is a one story building just outside the German section. It is located in a deserted area and the hotel has about nine or ten dark rooms. Moreover, there are no cars in front of the hotel. The description of the place suits the dangerous, illegal acts that take place inside it. In this room, Mink seduces 
volunteers to begin unsupervised experimentation that uses unknown and untested drug. He claims that this drug, Dylar, may relieve their fear of death. As a result of this pretext he seduced Babette, Jack's wife, to have an affair with him in return of pills of Dylar.

Thus, the hotel room becomes the place of infidelity, deceit and also the dangerous side effects of the untested drug. Jack decides to enter Mink's room in order to shoot him. Jack's shooting of Mink is the target of his retribution as a result of Mink's entrapment of Babette. Entering Mink's room, Jack finds an absent-minded, badly-dressed man. Mink stares vacantly into the TV without the sound as he goes on popping Dylar to his mouth. Thinking that Jack is another volunteer, Mink asks him if he knows "room behavior"(306). He explains that rooms are "inside" because people behave "one way in rooms, another way in streets, parks and airports"(306). This indicates the secretive, private nature of the indoors. He wants to keep what happens in his room as a secret as he is aware of its illegality. Jack shoots Mink twice and puts the gun in Mink's hand to let murder seem a suicide. Surprisingly, Mink is able to shoot Jack's wrist. At that moment a sudden change happens to Jack as a result of a strong gush of humanity. He changed his mind and decides to save Mink's life and take him to the hospital. Therefore, the hotel room becomes a place of attempted murder besides being a 
suspected place full of immorality and illegal deeds. However, it is the same place in which Jack achieves his moral balance and as he tries to save Mink's life, he drags him to the car.

Having decided to save Mink, Jack drove to a place "with a neon cross over the entrance"(315). It was a three-story building that "appeared to be a clinic" because there were waiting rooms, rooms for x-ray and a room for eye tests (316). The place was supervised by German doctors and run by nuns. Some of them worked on Mink's wounds and a nun took Jack into a cubicle to work on his wound. Throughout a discussion with one of the nuns, Jack astonishingly found out that they no longer believe in heaven, saints, angels, paradise and hell. She openly says to Jack "We are here to take care of sick and injured. Only this. You would talk about heaven, you must find another place"(318). Here the modern society with its flagrant lack of spirituality and devaluation of religious and spiritual values appears clearly. Even nuns behave in a pragmatic, materialistic way. The nun admits that their uniform is only to "pretend to believe these things" meaning heaven and hell (318). She protests saying "you would come in from the street dragging a body by the foot and talk about the angels who live in the sky. Get out from here"(320). Religion for her is only a pretense. Though she is a nun, she thinks only of her mundane function namely treating physical wounds. The 
place is not supposed to offer any kind of spiritual treatment. Its secular job is to save people's bodies not souls.

However, in the consuming society of White Noise the only place which is enjoyable for people is the supermarket and the happiest act is to do shopping. The supermarket is one of the central places in the novel. It represents both the clamor and temptation of modern capitalist consumerism. The supermarket is depicted as a place where people can exchange information and discuss different topics even philosophical points of view while pushing their carts. When Jack and Babette run into Murray at the supermarket, he tells them how he is affected by the generic packaging. He buys generic food and drink items in plain white packages with simple labeling. By doing so, he expounds that he feels "contributing to some kind of spiritual consensus"(18). Here, Murray gives everyday products a spiritual importance. He connects his spiritual state with purchasing specific goods. This is a salient manifestation of the decline of spiritual values in the modern world. Spirituality is equated to daily goods that can be sold at the supermarket. In the modern societies everything is for sale. Thus, on leaving the supermarket, Jack feels a sense of completeness resulted from the quality of their purchases. He considers the supermarket as a place of comfort and reassurance. The number of brightly colored products in their crowded bags gives their life a sense of fullness. It gives them "security and 
contentment"(20). This is because it satisfies their wish for possession and makes them feel wealthy.

Once again Murray meets Jack's family at the supermarket. While he is pushing Babette's loaded cart in a part of the store, Murray talks with her about the Tibetan philosophy of death. He is affected by the noises of the supermarket and the bright colors of goods that provide him with a psychic energy. Once again he confirms that "[t]his place recharges us spiritually"(37). This sheds clear light on the important role played by the supermarket in the life of modern societies. It is not only a place at which people purchase their commodities and materialistic needs but it is also a place that endows them with psychic comfort and spiritual energy. It is one of the central places at which people exchange opinions and discuss different topics while buying their needs. The supermarket in White Noise is an excellent example of what Masterson et al. call "place dependence". They define place dependence as the location that reveals the connection between people and place so that it shows "the ability of a setting to facilitate goal achievement and to satisfy important needs"(3).

Even after the panic of the airborne toxic event, it is the supermarket which was the source of safety. As long as the supermarket was well-stocked, bright and musical, "[e]verything was fine, would continue to be fine"(170). As it is the place that provides them with their needs, so it can help them overcome any 
problem whatever it is. Furthermore, everything "would eventually get even better as long as the supermarket did not slip"(170).

The last scene of the novel portrays the supermarket with its aisles, commodities and customers. There are people who wait together with their carts "stocked with brightly colored goods"(326). They wait in slowly moving lines and they are satisfied to have more time to look at the racks. In the supermarket everything is for sale. The place teems with goods that are attractive to people. As in the modern world there is not enough room for spiritual values, people depend on satisfying their materialistic needs to the full. It is a place of safety, security, discussions and entertainment.

Similar to the supermarket, is the Mid- Village Mall. During Jack's and his family's visit to the local shopping mall, Jack enjoys a sense of power and confidence as a consumer. Though their experience at the mall is positive, its effect is temporary as it ends when they leave the mall. Throughout their visit to the mall, Jack's family appears as a cohesive and unified family. They wander through shops consulting each other and moving from store to store. Moreover, they enjoy music, meals, popcorn and chocolate together. The place itself is decorated by waterfalls and gardens. Jack himself enjoys shopping for immediate and distant needs. He enjoyed the process of shopping in itself as money 
becomes less important for him. He lets children choose their own Christmas gifts and happily enjoys being "the benefactor, the one who dispenses gifts, bonuses, bribes, baksheesh"(84). Spending money reflects his generosity and financial power so enhancing his satisfaction and self-confidence. In the mall Jack acts as the strong man who has the upper hand and rejoices his family. Susana S. Martins argues that "the role-playing aspects of shopping - commanding store clerks, acting as the patriarch dispensing gifts to his family -lend Jack a deliberate, almost calculated sense of self-satisfaction" (11). However, at going back home, they preferred to be alone, everyone in his own room. Therefore, the pleasure of the feelings acquired in the mall is temporary and ends when they leave the place. The mall, like the supermarket, strengthens their familial bonds more than the house where they prefer loneliness.

From the above survey it is clear that place has become an important critical category. Any eco-critical study takes into consideration place and the necessary roles played by it in any work of art. The concept of place is not only concerned with outof -door locations but also with the indoor settings surrounding people. The study also shows the difference between setting as a direct place of action and place as a comprehensive symbolical concept. As place is connected to the subjective experience of a person, it has a lot of symbolical, emotional and psychological 
dimensions for him. It is not only a physical location that has a static meaning.

Examining the different places of White Noise proves that place is not only something urgent for characters but it also interacts with them and witnesses their various experiences. In addition to this, place in White Noise reveals the features of a postmodern society depending on technology, TV and its commercials, modern equipment, lack of moral and spiritual values, disintegrated houses, capitalistic consumerism, polluted environment and horrible fear of death. Moreover, place in this postmodern society changes the traditional stereotypes of specific places such as home as a private place of comfort, school as the place of education and the supermarket as a place only for purchasing the necessary daily needs. Furthermore, a large part of the novel takes place during the toxic event where nearly all the characters are placeless. At that time DeLillo greatly manages to depict homeless, perplexed and scared people in a fantastic epic style. Also, the other major places in the novel are affected by the personal experiences of the characters.

The houses of White Noise lack the unity and harmony of traditional families. Members of the family are isolated in their rooms most of the day. There is neither enough familial communication nor a fixed or a stable family structure. The domestic life of Jack's family is occasionally interrupted by 
frequent visits of former wives and husbands of Jack and Babette. Furthermore, these modern houses teem with electromagnetic radiation as a result of advanced technology. Moreover, the school is described as a place of contamination and toxic pollution where some teachers and students suffer from strange, dangerous symptoms.

Another place in White Noise is the camp in which placeless people live for nine days during the evacuation that takes place as a result of the toxic event. It shows the helplessness of the homeless people who were subjected to horrible conditions, dehumanization and terrible fear of death. Besides the camp, there is the place of the medical examination of Jack. It is a formal, stiff place in which people are treated as if they were nothing more than numbers and statistics. It reflects the lack of intimacy of the modern world.

However, the place that is rarely mentioned in literary works, especially when none of the principal characters lives in it, is the insane asylum. Though it does not play a prominent role in the events of the novel, it is depicted as a normal, factual necessity in the modern world. It ironically reveals the inability of the medical and technological advances to abolish insanity in the modern age. Furthermore, there is the hotel room in which Jack shoots the Dylar project manager and when he is shot by him, Jack decides to save his life and accompany him to a clinic. The room reflects 
the experience of Jack. It converts from the place of revenge and attempted murder to a place of human tolerance and sympathy. Also, the clinic where they go, is a deserted place run by nuns. Through a conversation between Jack and one of the nuns, he discovers that religion for her is just a pretense. She rebukes him saying that her main job in that place is to treat the wounds and the diseases of the body to save people's lives. She has no concern with spirituality or religious believes. Again the place reflects the materialistic nature of the modern world.

The study also reaches the conclusion that the only place which brings comfort and happiness to the characters of the novel is the supermarket. It is the place in which they spend a lot of time and satisfy their need for possession. It shows the modern society as a consuming society whose most important pleasure is to accumulate brightly- colored commodities in their carts. The real happiness of Jack's family together appears only during their visit to the supermarket and the local mall of the town. It is a place of entertainment and enjoyment where they enjoy spending money as a sign of financial power and social prestige.

Thus place is a very important critical concern in White Noise. Don DeLillo successfully employs this element in order to show how place affects the personal qualities of a character. Place reflects the human, emotional and moral values of its people. It also interacts with them during their sad and happy experiences. 
Place plays its effective role in forming a great part of a person's character. Places in White Noise are suitable for the postmodern society which they portray and the conduct and values of people at that time. 


\section{Works Cited}

Ball, Eric L. "Literary Criticism for Places". Symploke, vol. 14, no. 1/2, Discouragement. University of Nebraska Press,2006, pp.232251.

DeLillo, Don. White Noise. USA: Viking Penguin Inc., 1985.

Devetak, Richard. "After the event: DeLillo's White Noise and September 11 narratives". Review of International Studies, vol. 35, no. 4, Cambridge University Press, October 2009, pp. 795-815.

Fledman, Mark B. and Hsu, Hsuan L. "Introduction: Race, Environment, and Representation". Discourse, Special Issue: Race, Environment, and Representation. vol. 29, no. 2/3, Wayne State University Press, Spring \& Fall 2007.

Gladwin, Derek."Ecological and Social Awareness in Place-Based Stories". The Canadian Journal of Irish Studies, vol. 42, 2019, pp. 138-157.

Kibler, Kelly M. et al. "Integrating Sense of Place to Ecosystem Restoration: A Novel Approach to Achieve Synergistic SocialEcological Impact". Ecology and Society, vol. 23, no. 4, Resilience Alliance Inc., Dec 2018.

Kincheloe, Joe L. and William F. Pinar. Curriculum as Social Psycho Analysis: The Significance of Place. Suny Press, 1991.

Kortetmaki, Teea. "Is Broad the New Deep in Environmental Ethics? A Comparison of Broad Ecological Justice and Deep Ecology". Ethics and Environment, vol. 21, no. 1, Indiana University Press, Spring 2016, pp., 89- 108.

Love, Glen A. "Ecocriticism and Science: Toward Consilience?" New Literary History, vol. 30, no. 3, The Johns Hopkins University Press, Summer 1999, pp., 561- 576.

Lutwack, Leonard. The Role of Place in Literature. Syracuse UP., 1984.

Martins, Susana S. "White Noise and Everyday Technologies". American Studies, vol. 46, no. 1, American Studies Association, Spring 2005, pp. 87- 113. 
Masterson, Vanessa A. et al. "The Contribution of Sense of Place to Social- Ecological Systems Research: A Review Research Agenda". Ecology and Society, vol. 22, no. 1, Resilience Alliance Inc., Mar 2017.

Morris, Marla. "Ecological Curriculum Concepts". Counterpoints, vol. 499, Curriculum Studies Guidebooks: Concepts and Theoretical Frameworks, vol. 2, Peter Lang AG, 2016, pp. 127-172. Reeve, N. H. and Richard Kerridge. "Toxic Events: postmodernism and DeLillo's White Noise". The Cambridge Quarterly, vol.23,no.4, Oxford University Press, 1994, pp., 303- 323. 


\section{دراسه بيئيه مكانيه لرواية الصخب الأبيض لدون ديليللو}

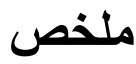

لقد أصبح مفهوم المكان موضوعاً بحظى باهتمام أساسى فى معظم الأعمال التى تتناول موضوعا بيئيا • والغرض من هذه الدراسه هو فحص رواية "الصخب

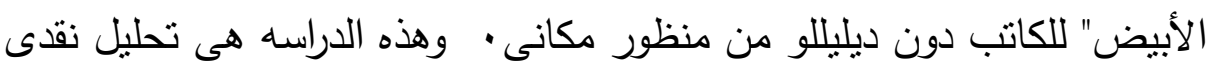

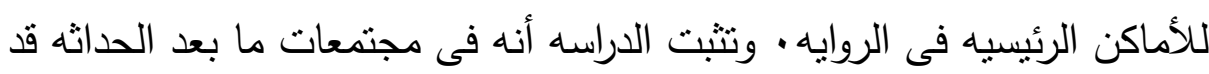
انعكست الفكره السائده عن المنزل كمكان آمن ومريح والدحل التجارى كمجرد

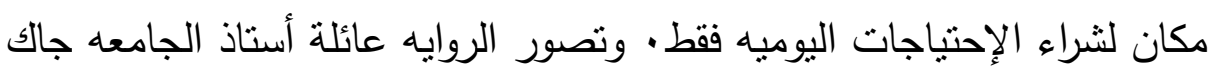
جلادنى التى نعيش فى بلده حديثه تسمى بلالك سميث • ومع ذلك يتتبع جزء كبير من الروايه حادث انقلاب عربتين من قطار محمل بخزانات مليئه بغاز سام

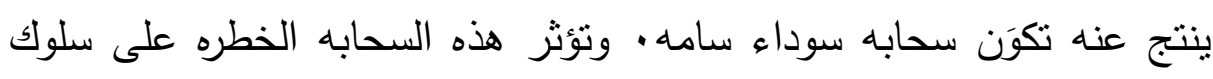

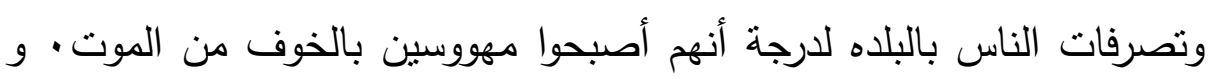

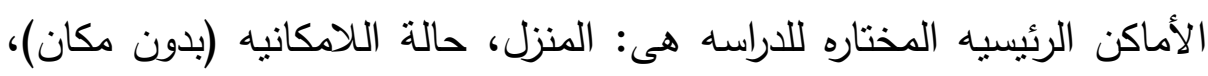

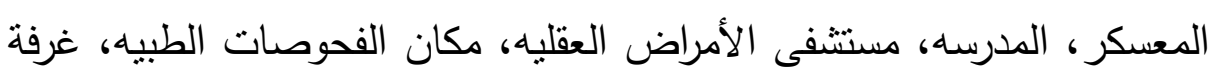

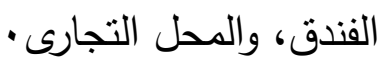

الكلمات المفتاحيه:النقـ البيئى، العداله البيئيه، الانتحار البيئى (تدمير البيئه)، الثعور بالمكان، الصخب الأبيض، دون ديليلو 